\title{
SALMONELLA SPP. IN PET FEED AND RISK IT POSES TO HUMANS
}

\author{
Dubravka S. Milanov ${ }^{1}$, Nevenka R. Aleksić ${ }^{2}$, Suzana S. Vidaković ${ }^{1}$, Dragana B. Ljubojević ${ }^{1}$, Ivana S. \\ Čabarkapa ${ }^{3}$ \\ ${ }^{1}$ Scientific Veterinary Institute "Novi Sad“, 21000 Novi Sad, Rumenački put 20, Serbia \\ ${ }^{2}$ University of Belgrade, Faculty of Veterinary Medicine, 11000 Belgrade, Bulevar oslobođenja 18, \\ Serbia \\ ${ }^{3}$ University of Novi Sad, Institute of Food Technology, 21000 Novi Sad, Bulevar cara Lazara 1, Serbia
}

\author{
*Corresponding author: \\ Phone: +38162 210012 \\ Fax: +381112685936 \\ E-mail address: nenaaleksic@vet.bg.ac.rs
}

\begin{abstract}
Commercial feed intended for dogs and cats is an almost unrecognised source of human infection with various serovars of Salmonella enterica. However, people may catch the infection both via direct contact with contaminated pet feed and by contact with pets, which usually shed Salmonella without signs of infection. A relatively new trend of feeding dogs and cats with raw feed is considered to be a special risk owing to the fact that it usually contains foodborne pathogens, such as Salmonella spp., Escherichia coli and Campylobacter spp. Nonetheless, the epidemiological data do not support this idea. In the current review relevant data on the significance of pet feed in the outbreak of human salmonellosis are discussed and the recommendations for the prevention of the infection originating from these sources are suggested.
\end{abstract}

Key words: pets, raw and commercial feed, salmonellosis

\section{INTRODUCTION}

It is considered that human infections with nontyphoidal Salmonella enterica serovars usually in $55 \%$ to $95 \%$ cases result from ingestion of contaminated food and in some $9 \%$ from direct contact with animals. Pets are thought to be involved in about 3\% (Lowden et al., 2015). In developed countries, cats and dogs are the most popular household animals by far, which spend the majority of their lives in the close vicinity of their owners. In 2017/18, in the USA there were 89.7 million dogs and 94.2 million cats (I.I.I., 2019), and in the UK 8.9 million dogs and 11.1 million cats, according to The Peoples Dispensary for Sick Animals report (PDSA, 2018). Pet dogs are also numerous in Serbia: in recent years about 40,000 puppies are being registered at the Serbian Cynology Association annually, but the number on new-borns is supposed to be much higher owing to a considerable number of crossbreed dogs which do reproduce but their litters remain unrecorded. It is estimated that Serbia is a "dog country" given the number of these animals in relation to human population.

It is estimated that out of the known 250 zoonoses 30-40 are associated with cats and dogs (Moriello, 2003). Ectoparasites, such as ticks and fleas, which are not much selective and readily attack people and various animal species, are easily recognizable and usually do not cause severe problems. By contrast, the parasitism of larval and adult nematodes (toxocarosis 
and dirofilariosis, respectively), and cestode infections (echinococcosis) is incomparably more problematic, as well as leishmaniosis, giardiosis (Baneth et al., 2016), and toxoplasmosis (Salman et al., 2018). There are also certain bacterial infections closely related to companion animals such as the cat scratch disease, psittacosis, leptospirosis, campylobacteriosis and salmonellosis (Damborg et al., 2016). The latter is regarded as the most serious bacterial disease common to animals and humans. Dogs and cats can contract salmonella infection when hunting, mainly rodents and birds, or from carcasses which they may come in contact with. For companion animals, the sources of infection may be some other pets, such as reptiles (lizards, snakes and turtles) or amphibians (frogs), which are natural reservoirs of these bacteria (Rijks et al., 2016). However, the most important source of Salmonella is commercial feed intended for pets. It may be a potential source of infection of both animals and humans (Giacometti et al., 2017). People can contract the infection by direct contact with contaminated feed, as well as with pets which usually shed Salmonella without clinical signs of infection. Various serovars of Salmonella may be isolated from pet feed, including the two of the highest epidemiological importance: Enteritidis and Typhymurium, as well as Salmonella strains resistant to important antibiotic classes, even to third-generation cephalosporins ( $\mathrm{Li}$ et al., 2011). Here, relevant data on the poorly known risk pet feed poses to public health are presented.

\section{SALMONELOSISS IN CATS AND DOGS}

Salmonellosis in dogs and cats is not considered to be a common disease. Clinical signs of the infection are rarely present, which contributes to its unknown prevalence (Carter and Quin, 2000). It is supposed that about $10 \%$ of dogs were at some time in their life infected with Salmonella spp. (Morse et al., 1976). Seemingly healthy dogs and cats which were infected orally intermittently shed salmonella in faeces for more than 6 weeks, in concentrations which vary from $10^{2}$ to $10^{5}$ CFU/g faeces (Carter and Quin, 2000). Salmonella were isolated from $0-14 \%$ faecal samples of apparently healthy cats (Center et al., 1995), and 0-43\% nonsymptomatic dogs (Carter and Quin, 2000). Research showed that the prevalence of Salmonella in the feaces of asymptomatic dogs was $2.4 \%$ in Italy (Nastasi et al., 1986), 3.45\% in Germany (Weber et al., 1995) and $1.2 \%$ in rural dogs in eastern Washington in 1951 (Gorham et al., 1951).

In the US, 11 laboratories collaborated to determine the prevalence of Salmonella in dogs and cats visiting veterinary surgeons (Reimschuessel et al., 2017). A total of 2,965 faecal samples were collected in 36 states from 2012 to 2014 . The prevalence of Salmonella in both species was low: in dogs $2.5 \%$ (60 out of 2,422) and in cats $<1 \%$ (3 out of 542 ). Recently, the prevalence of Salmonella in the faeces of dogs from the UK was also confirmed to be very low: faecal samples from 436 apparently healthy dogs were tested for Salmonella shedding and only one dog $(0.23 \%)$ was proved to be positive for Salmonella, specifically $S$. enterica subsp. arizonae (Lowden et al., 2015).

Infected animals can remain carriers for a considerable time due to the presence of Salmonella in their lymph nodes: for example, S. infantis was confirmed in the faeces of dogs throughout a 117-day period following the experimental infection (Morse et al., 1976). However, not one serovar is considered to be adapted specifically to the cat or the dog, unlike some of them adhered to other animal species (Carter and Quin, 2000). In dog faeces and anal swabs 53 Salmonella serovars were identified so far. Their prevalence differed depending on the geographic region. Salmonella Typhimurium is the most frequently detected serovar in dogs (Cantor et al, 1997) and cats (Stiver et al., 2003).

\section{EPIDEMIOLOGY OF HUMAN SALMO- NELOSSIS CONECTED WITH PETS FEED}

Pet feed contains more than $60 \%$ animalderived ingredients. Given that complete feed mixtures for non-carnivorous animal species consist of approximately $2 \%$ of these, the former run a higher risk of being 
contaminated with Salmonella. Feed which will not be subjected to thermal treatment before use, such as raw meat and raw products derived from poultry intended for cats and dogs, chews for pets, mineral, vitamin and other companion animal feed supplements, ingredients of pet feed (cereal- and plant-derived protein products, vitamins and minerals) are especially endangered. FDA's Compliance Policy Guide (690.800) entitled "Salmonella in food from animals" requires regulatory actions when in animal feed Salmonella serovars are detected which are the causes of diseases in animals it is intended for: when in poultry feed Salmonella Pullorum, Salmonella Gallinarum, or Salmonella Enteritidis are found; in swine feed Salmonella Choleraesuis, in sheep feed Salmonella Abortusovis, in horse feed Salmonella Abortusequi, and in dairy and beef feed(s) Salmonella Newport or Salmonella Dublin (FDA, 2013). For companion animal feed, FDA proposes regulatory action in case of contamination with any of the serovars of Salmonella due to the risk to human health.

If contaminated with foodborne pathogens, pet feeds, may pose a serious health risk to people who handle these products (Nemser et al., 2014). People can acquire the infection directly, when handling contaminated pet feed, bowls or some other types of dishes for feeding and indirectly, when in contact with cats or dogs harbouring covert infection. Young children are at highest risk of catching the infection via unwashed hands, so are the elderly, pregnant women and adults with decreased functions of the immune system due to some other concomitant disease (Behravesh et al., 2010). The association between the epidemics of salmonellosis in people and contaminated commercial feed intended for pets is well documented. According to the published data, between 1999 and 2013 there were more than 150 outbreaks of human salmonellosis in the USA and Canada which were in some way connected to cat and dog feed contaminated with Salmonella.

In the summer of 1999, an outbreak of human salmonellosis happened in Alberta (Canada). The source of infection was identified: treats for dogs produced from processed pig ears contaminated with $S$. Infantis (CCDR, 2000). After this outbreak, Salmonella spp., including $S$. Infantis, were isolated in $51 \%$ treats for dogs from shops in Canada and from $41 \%$ samples of the same feed in shops in the USA (CDC, 2006). S. Infantis was not quantitatively assessed in these products (Clark et al., 2001). In Canada, only 9 cases of salmonella infection were confirmed, but due to the often-self-limiting infection, it was considered that the outbreak may have involved hundreds of people. The first case was confirmed in a man who suffered from diarrhoea, by detecting Salmonella Thompson. Several days before having been ill he fed his dog treats made of beef; the animal remained asymptomatic. The target feed was examined and Salmonella Thompson, Cerro and Meleagridis were isolated. Pulsedfield gel electrophoresis (PFGE) detected identical profiles of $S$. Thompson isolated from dog feed and from the stool of the dog owner. A similar case happened after a woman fed her dog treats made from salmon, but her dog suffered from diarrhoea (in 2005): in both the owner and the dog $S$. Thompson was detected. Further, in an elderly woman suffering from hyperthermia, vomiting and diarrhoea $S$. Thompson was confirmed, as well as in treats made from beef she fed her dog with; again, the dog remained asympto-matic. In another 6 cases of human salm-onellosis $S$. Thompson was confirmed, genetically identical to those previously detected in the USA and Canada; all these people were in contact with pet feed and/or pets (CDC, 2006). Pet treats were prepared by cutting and shaping thawed meat, dehydrating and packing prior to placement in the market. The following Salmonella serovars were detected in pet feed: Montevideo, Newport, Give, Meleagridis, Cerro, Muenster, Agona and Anatum. Those produced from salmon were heavily contaminated - with more than 80,000 CFU of $S$. Thompson per gram (CDC, 2006). Interestingly, however, not one label warned people to wash their hands on handling the product.

Human salmonellosis clearly associated with dry pet food, were first reported by 
Behravesh et al. (2010). The primary victims of this Salmonella Schwarzen-grund outbreak, $48 \%$ of 79 diseased people throughout the USA (21 states) in a threeyear-period, were young children under the age of two. Recent purchase of a certain brand of dry pet feed and feeding in kitchens correlated highly with disease outbreaks. S. Schwarzengrund were isolated from opened bags of dry dog food, faecal samples from dogs which were fed on that food, environmental samples and unopened bags of dog and cat foods. Consequently, about 23,000 tons of products were recalled by the producer, who after additional outbreaks in 2008, recalled 105 brands of its dry pet food and permanently closed the plant which produced the feed.

In 2017, 90 people from 26 USA states were diagnosed with infection caused by genetically related strains of Salmonella Reading (FDA, 2018). One of them, a child developed septicaemia and osteomyelitis. Salmonella Reading was detected in feed samples the family kept for their dog. It was ground food made from turkey.

\section{ARE PETS AND HUMANS AT RISK FROM (RAW) FEED?}

There are three types of commercial pet feed: dry feed (also known as kibble), semi-moist products and treats. They contain a wide variety of ingredients: wheat and maize flour or semolina, soya flour, meat and fish meal, animal or vegetable oils and minerals, amino acids and vitamins, additives such as those added for texture, flavour enhancers and preservatives. Methods used for commercial feed production decrease its nutritive value, destroy essential nutrients and enzymes and may cause some chronic health problems. Dry pet feed contains components which cannot be found in raw food, including highly carcinogenic mycotoxins, not to mention some very serious vitamin and mineral excesses and insufficiencies. Relatively new products used in dog and cat diet are chews resulting from abattoir by-products: pig ears, bull pizzles, pig and cattle feet, as well as raw feed intended for complete meals made of meat, vegetables and cereals.
Intolerance of kibble in a number of pets prompted the search for alternatives. Feeding dogs and cats with raw food, which includes raw meat, bones, fruit and vegetables, was proposed by lan Billinghurst, an Australian veterinary surgeon and nutritionist, in 1993. He even coined the acronym BARF, a quite inappropriate one, given the meaning of the word "barf". However, here it means the use of Biologically Appropriate Raw Food or Bones and Raw Food, and accordingly - BARF diet. Since then, various commercial feed types have emerged on the market including frozen, cryodesiccated feed, and those made of raw meat with the addition of grains, vegetables and some vitamins. Consumption of raw meat and vegetables is considered beneficial for animal health, owing to the resemblance to their evolutionary established feeding habits. However, there are vehement opponents of this type of diet, who think it is concerning due to the fact that in raw meat there is a possibility of the presence of various pathogenic microorganisms, especially of Salmonella.

Feeding companion animals on food containing raw meat is a widespread practice, although if contaminated with certain bacteria, these diets may be sources of animal and human diseases (van Bree et al. 2018). In the Netherlands samples of commercial frozen pet feed containing meat, produced by various producers, were tested for the presence of zoonotic bacteria. Salmonella spp. were confirmed in $20 \%$ (7 out of 35 ) products, which also proved that these types of pet feed are a possible source of infections to pet animals and, if transmitted, for pet owners too. However, there were no literature data on clinical salmonellosis in dogs caused by raw food before 2002 (Joffe and Schlesinger, 2002).

The dog and the cat are innately highly resistant to salmonella, which is why the use of raw feed in their diet is questionable primarily from the public health viewpoint. Raw pet diets threaten human health due to the shedding of salmonella by asymptomatic dogs and the resulting contamination of the environment. To assess the risk, 10 healthy dogs not treated in the 
previous two months with antibiotics were fed on either commercial or raw feed. Diet and stool samples were taken on a daily basis. Salmonella ( $S$. Braenderup, $S$. Schwarzengrund and $S$. Hadar) was isolated from 8 out of 10 of the BARF samples and from 3 in 10 stool samples of dogs fed the diet (Joffe and Schlesinger, 2002). Although in one case only the same salmonella serovar was confirmed in both the feed and the consumer dog faeces, it was concluded that the presence of faecal serovars were a consequence of previous consumption of raw feed.

Salmonella were isolated from faeces of considerable numbers of Alaskan sled dogs - 69\% (Cantor et al., 1997) and $36.5 \%$ from racing hounds in Florida (Stucker et al., 1952). High prevalence of salmonella in these breeds is directly associated with diets based on raw meat and fats, necessary to satisfy high demands for energy. Interestingly, although diarrhoea is one of the most common problems in sled dogs during long-distance races, the prevalence of Salmonella in dogs with diarrhoea and those asymptomatic was found to be similar: $63 \%$ (19/30) in the former and $69 \%(18 / 26)$ in the latter (Cantor et al., 1997). S. Typhimurium or $S$. Typhimurium (Copenhagen) was detected in 13 healthy and 10 diseased dogs (Cantor et al., 1997).

Owing to the failure to detect significant differences in the prevalence of Salmonella in healthy and diseased dogs, the role of these bacteria in diarrhoea remains unclear. What is sure is that the diagnosis of salmonellosis cannot be established based on the conformation of these in faeces (Cantor et al., 1997). In addition, although salmonellosis is present in humans in Alaska, a direct connection between the dogs and/or dog feed with human disease remained unconfirmed.

On average, about $50-75 \%$ meals of racing dogs is composed of raw meat originating from rendering plants, which means from diseased, debilitated, dying or dead animals. Meat is there ground and frozen, and before use it is thawed at room temperature and mixed with some other ingredients (Chengappa et al., 1993). Meat is not subjected to thermal treatment, which is why bacteria, including foodborne pathogens (E. coli, Campylobacter and Salmonella) are usually present (Chengappa et al, 1997). Racing sled dogs need high-calorie feed which are palatable to satisfy their needs during exhausting races. It usually comprises commercial, high-fat dog foods, and meat and fat originating from various animal species (Cantor et al., 1997).

On one occasion, 112 samples of raw meat used for feeding greyhounds were checked for Salmonella using both standard microbiological procedures and a commercial DNA assay. Salmonella was isolated from $44.46 \%$ samples, but as many as $66.03 \%$ were positive in the DNA test (Chengappa et al., 1997). Hounds acquire Salmonella from raw meat, which may be deleterious to the young: almost all the puppies may develop clinical salmonellosis and mortality may reach almost 40\% (Chengappa et al., 1997).

In research conducted in the USA, 60 out of 2422 dogs were found to be Salmonella-positive (Reimschuessel et al., 2017). Consumption of raw food was identified as a major risk factor for Salmonella infection; a significant difference in the number of dogs fed raw food between those positive and negative for Salmonella was revealed: $16.7 \%$ of positive dogs were fed raw food, but only $7.2 \%$ of negative ones. Rural dogs were more likely to harbour Salmonella than their urban or suburban counterparts. The analysis pointed to an overall decline in the prevalence of Salmonella-positive dogs over the last decades.

An extensive survey analysed 1056 samples of pet feeds in the USA over 2 years (Nemser et al., 2014). Tests for Salmonella were performed on 480 dry and semi-moist dog and cat foods and only one, a sample of cat dry food was found to be positive. However, out of 576 samples of raw dog and cat foods, exotic animal feed and jerky-type treats 15 samples were positive for Salmonella - and all were raw foods.

A number of non-specific immunity factors contribute to the resistance of dogs and cats to infection: gastric contents $\mathrm{pH}$, the 
quality of intestinal mucous, lysozyme in secretions, peristalsis, lactoferrin in the intestinal tract and the intestinal microbiome. Phagocyte cells are extremely important owing to the fact that salmonella multiply in these. Adult, immunocompetent animals will show signs of infection if exposed to high doses or to contributing non-specific factors, such as a concomitant disease (diabetes or cancer), stressors (medical treatments, surgery, poor diet, certain environmental conditions, such as overcrowding, and inadequate heating, humidity and lighting), immunosuppressive therapy, antibiotics which disturb the intestinal microbiome and create conditions for the colonisation and fast reproduction of salmonella etc. (Carter and Quin, 2000). Immunosuppression plays an important role in clinical salmonellosis in dogs, which is why it is often associated with vaccination or a virus enteritis (Chengappa et al., 1997). An incompetent immune system and underdeveloped microbiome in the intestines render young animals susceptible to salmonella infection.

Two cats from the same household in Georgia (US) were diagnosed post mortem with gastroenteritis and septicemia caused by Salmonella (Stiver et al., 2003). Salmonella Newport was isolated from the organs of one of the cats and from raw beef used for preparing their feed. This was one proof more that consumption of feed containing raw meat in cats may result in clinical salmonellosis. There was a similar case of salmonellosis in Italy: two cats fed with commercial, frozen poultry meet developed clinical signs of gastrointestinal disease. Faecal analyses revealed only one pathogen - Salmonella. That was the first report of salmonellosis following raw feed consumption in two animals from the same household in Italy (Giacometi et al., 2017).

Until recently, there were no documented cases of human salmonella infections which could have been associated with pets' consumption of raw feed (Finley et al., 2006). The first case with proven direct connection between those was notified in Minnesota, USA, in 2018, when in two diseased children the same type of Salmonela was detected as in commercial raw dog feed made from turkey meat and bones (Brady, 2018). However, it remained unknown whether the infection resulted from contact with feed or with pets which consumed the feed. Consequently, $5,000 \mathrm{~kg}$ of the product were recalled.

\section{CONCLUSIONS AND RECOMMENDATIONS}

Due to the risk of feed being contaminated with Salmonella (and some other zoonotic bacteria), care should be taken when opting for raw food to feed pet with (FDA, 2018), especially if there are young children or elderly in the household, who may come in immediate contact with these pets. Awareness is needed of the risk that pets may shed Salmonella.

Pet owners and/or animal caretakers must regularly thoroughly wash their hands using soap after each contact with feed intended for cats or dogs (Behravesh et al., 2010). Pet feed and utensils must not be kept in the kitchen. All surfaces (including floors, pet toys and bedding) which may have been in contact with pet food must be cleaned thoroughly and without exception. In addition, it is also important to properly handle and store dry pet feeds at home to prevent human disease, especially among young children (Behravesh et al., 2010; Nemser et al., 2014).

General cooperation between veterinary and medical professionals and joined attempts at improved health education help reduce the risks of foodborne and/or zoonotic infections and accept the 'One Health' concept (Sterneberg et al., 2016).

Being a competent source of information for pet owners, veterinary surgeons should advise them on the safety of pet foods and treats, provide information about potential contamination risks, for example with Salmonella, so that appropriate measures be implemented (KuKanich, 2011). Despite the low risk of catching salmonellosis from contaminated pet feed, compliance with safety recommendations will contribute to minimizing the risk of infections of pets and their owners.

The estimation of risks and benefits for people suffering from immunosuppressive 
diseases or undergoing immunosuppressive therapies from their interaction with pets has always been questionable: zoonotic infections are usually more severe and may be lethal in these patients (Elad et al., 2013). Consultations between the patient, the medical doctor and the veterinary surgeon are of utmost importance in the evaluation of potential health risks, although the pet owner is to decide if they will keep pets.

Due to the shortage in data on zoonotic bacteria prevalence in pet populations and on the incidence of human infections attributable these (Damborg, et al., 2016), and few studies on foodborne diseases in companion animals (Giacometti et al., 2017), further research is needed to confirm the link between companion animals, pet feed and human salmonellosis.

Further, it is of utmost importance to establish a system for the identification of dogs and other companion animals using implantted microchips with all necessary information on the owner and the pet, and storage of these data in an online database (Sterneberg-van der et al., 2016), which has partly been completed in Serbia. The investigation into the putative sources and transmission pathways of salmonellosis could be helped by applying whole-genome sequencing data combined with evolutionary modelling (Mather et al., 2018).

\section{ACKNOWLEDGEMENTS}

This work was supported by the Ministry of Education, Science and Technological Development of the Republic of Serbia, by awarding grants for research projects No. 31071 and III46002.

\section{REFERENCES}

1. Baneth, G., Thamsborg, S.M., Otranto, D., Guillot, J., Blaga, R., Deplazes, P., SolanoGallego, L. (2016). Major parasitic zoonoses associated with dogs and cats in Europe. Journal of Comparative Pathology, 155 (1), S54-S74.

2. Behravesh, C.B., Ferraro, A., Deasy, M., Dato, V., Moll, M., Sandt, C., Rea, N.K., Rickert, R., Marriott, C., Warren, C., Urdaneta, V., Salehi, E., Villamil, E., Ayers, T., Hoekstra U. R., Austin, J.L., Ostroff, S., Williams, I.T. (2010). Human Salmonella infections linked to contaminated dry dog and cat food, 2006-2008. Pediatrics, 126 (3), 477-483.
3. Brady, C. (2018). The first case of Salmonella transmission from raw dog food. (Retrieved February 20, 2019 from https://dogsfirst.ie/firstcase-of-salmonella-from-raw-dog-food/).

4. Cantor G.H., Nelson S., Vanek J.A., Evermann J.F., Eriks I.S., Basaraba R.J., Besser T.E. (1997). Salmonella shedding in racing sled dogs. Journal of Veterinary Diagnostic Investigation, 9 (4), 447-448.

5. Carter M.E., Quin P.J. (2000). Salmonella infections in dogs and cats, (Chapter 14). In Salmonella in Domestic Animals. Eds. C. Wray, A. Wray, CAB International, Wallingford, Oxfordshire, UK, pp. 231-244.

6. (CCDR) Canada Communicable Disease Report (2000). Human health risk from exposure to natural dog treats. Canada Communicable Diseases Report Monthly, 26 (6), 41-42. (Retrieved February 18, 2019 from http://publications.gc.ca/collections/Collection/H 12-21-26-6.pdf).

7. (CDC) Centers for Disease Control and Prevention (2006). Update: Human Salmonellosis associated with animal-derived pet treats-United States and Canada, 2005. Morbidity and Mortality Weekly Report, 55 (25), 702-705. (Retrieved February 20, 2019 from https://www.cdc.gov/mmwr/preview/mmwrhtml/ mm5525a3.htm).

8. Center, S.A., Hornbuckle, W.E., Hoskins, J.D. (1995). The liver and pancreas. In Veterinary Pediatrics. Eds. J.D. Hoskins, W.B. Saunders, Philadelphia, USA, pp. 212-213.

9. Chengappa, M.M., Staats, J., Oberst, R.D., Gabbert, N.H., McVey S. (1993). Prevalence of Salmonella in raw meat used in diets of racing greyhounds, Journal of Veterinary Diagnostic Investigation, 5 (3), 372-377.

10. Clark, C., Cunningham, J., Ahmed, R., Woodward, D., Fonseca, K., Isaacs, S., Ellis, A., Anand, C., Ziebell, K., Muckle A., Sockett, P., Rodgers, F. (2001). Characterization of Salmonella associated with pig ear dog treats in $\mathrm{Ca}-$ nada. Journal of Clinical Microbiology, 39 (11), 3962-3968.

11. Damborg, P., Broens, E.M., Chomel, B.B., Guenther, S., Pasmans, F., Wagenaar, J.A., Weese, J.S., Wieler, L.H., Windahl, U., Vanrompay, D., Guardabassi, L. (2016). Bacterial zoonoses transmitted by household pets: stateof-the-art and future perspectives for targeted research and policy actions. Journal of Comparative Pathology, 155 (1), S27-S40.

12. Elad, D. (2013). Immunocompromised patients and their pets: still best friends? The Veterinary Journal, 197 (3), 662-669.

13. FDA (2013). Guidance for FDA Staff Compliance Policy Guide Sec. 690.800 Salmonella in Food for Animals. (Retrieved February 19, 2019 from

https://www.fda.gov/downloads/ICECI/Complia nceManuals/CompliancePolicyGuidanceManual IUCM361105.pdf)

14. FDA (2018). FDA Investigates outbreak of Salmonella infections linked to Raws for paws ground turkey food for pets. (Retrieved February 15, 2019 from 
https://www.fda.gov/animalveterinary/newseven ts/ucm596071.htm)

15. Finley, R., Reid-Smith, R., Weese, J.S. (2006). Human health implications of Salmonellacontaminated natural pet treats and raw pet food. Clinical Infectious Diseases, 42 (5), 68691.

16. Giacometti, F., Magarotto, J., Serraino, A., Piva, S. (2017). Highly suspected cases of salmonellosis in two cats fed with a commercial raw meat-based diet: health risks to animals and zoonotic implications. BMC Veterinary Research, 13 (1), 224.

17. Gorham, J.R., Garner, F.M. (1951). The incidence of Salmonella infections in dogs and cats in a nonurban area. American Journal of Veterinary Research, 12, 35-37.

18. I.I.I. (2019). Facts + Statistics: Pet statistics. Insurance Information Institute, Inc., NY, (Retrieved February 8, 2019 from https://www.iii.org/fact-statistic/facts-statisticspet-statistics).

19. Joffe, D.J., Schlesinger, D.P. (2002). Preliminary assessment of the risk of Salmonella infection in dogs fed raw chicken diets. Canadian Veterinary Journal, 43 (6), 441-442.

20. KuKanich, K.S. (2011). Update on Salmonella spp. contamination of pet food, treats, and nutritional products and safe feeding recommendations. Journal of the American Veterinary Medical Association, 238 (11), 1430-1434.

21. Li, X., Bethune, L.A., Jia, Y., Lovell, R.A., Proescholdt, T.A., Benz, S.A., Schell, T.C., Kaplan, G., McChesney, D.G. (2012). Surveillance of Salmonella prevalence in animal feeds and characterization of the Salmonella isolates by serotyping and antimicrobial susceptibility. Foodborne Pathogens and Disease, 9 (8), 692-698.

22. Lowden, P., Wallis, C., Gee, N., Hilton, A. (2015). Investigating the prevalence of Salmonella in dogs within the Midlands region of the United Kingdom. BMC Veterinary Research, 11 (1), 239. (Retrieved February 16, 2019 from https://bmcvetres.biomedcentral.com/track/pdf/ 10.1186/s12917-015-0553-z).

23. Mather, A.E., Vaughan, T.G., French, N.P. (2015). Molecular approaches to understanding transmission and source attribution in nontyphoidal Salmonella and their application in Africa. Clinical Infectious Diseases, 61(suppl_4), S259-S265.

24. Moriello, K.A. (2003). Zoonotic skin diseases of dogs and cats. Animal Health Research Reviews, 4 (2), 157-168.

25. Morse, E.V., Duncan M.A., Estep, D.A. Riggs, W.A., Blackburn, B.O. (1976). Canine Salmonellosis: A review and report of dog to child transmission of Salmonella enteritidis. American Journal of Public Health, 66 (1), 82-84.

26. Nastasi, A., Massenti, M.F., Scarlata, G., Mammina, C., Calco, C., Villafrate, M.R. (1986). Salmonella and Yersinia enterocolitica in soil and dog faeces. Bollettino dell' Istituto Sieroterapico Milanese, 65 (2), 150-152.

27. Nemser, S.M., Doran, T., Grabenstein, M., McConnell, T., McGrath, T., Pamboukian, R., Smith, A.C., Achen, M., Danzeisen, G., Kim, S., Liu, Y. (2014). Investigation of Listeria, Salmonella, and toxigenic Escherichia coli in various pet foods. Foodborne Pathogens and Disease, 11 (9), 706-709.

28. PDSA (2018). How many pets are there in the UK? Paw Report 2018. The Peoples Dispensary for Sick Animals, UK, Veterinary charity organization, (Retrieved February 8, 2019 from

https://www.pdsa.org.uk/get-involved/ourcampaigns/pdsa-animal-wellbeing-report/ukpet-populations-of-dogs-cats-and-rabbits).

29. Reimschuessel, R., Grabenstein, M., Guag, J., Nemser, S. M., Song, K., Qiu, J., Clothier, K.A., Byrne, B.A., Marks, S.L., Cadmus, K., PabiIonia, K., Sanchez, S., Rajeev, S., Ensley, S., Frana, T.S., Jergens, A.E., Chappell, K.H., Thakur, S., Byrum, B., Cui, J., Zhang, Y., Erdman, M.M., Rankin, S.C., Daly, R., Das, S., Rijks, J.M., Cito, F., Cunningham, A.A., Rantsios, A.T., Giovannini, A. (2016). Disease risk assessments involving companion animals: an overview for 15 selected pathogens taking a European perspective. Journal of Comparative Pathology, 155 (1), S75-S97.

30. Salman, D., Pumidonming, W., Oohashi, E., Igarashi, M. (2018). Prevalence of Toxoplasma gondii and other intestinal parasites in cats in Tokachi sub-prefecture, Japan. Journal of Veterinary Medical Science, 80 (6), 960-967.

31. Sterneberg van der Maaten T., Turner D., Van Tilburg J., Vaarten J. (2016). Benefits and risks for people and livestock of keeping companion animals: searching for a healthy balance. Journal of Comparative Pathology, 155 (1), S8-S17.

32. Stiver, S.L., Frazier, K.S., Mauel, M.J., Styer, E.L. (2003). Septicemic Salmonellosis in two cats fed a raw-meat diet. Journal of the American Animal Hospital Association, 39 (6), 538542.

33. Stucker, C.L., Galton, M.M., Cowdery, J., Hardy, A.V. (1952). Salmonellosis in dogs. II. Prevalence and distribution in greyhounds in Florida. Journal of Infectious Diseases, 91 (1), 6-11.

34. van Bree, F.P., Bokken, G.C., Mineur, R., Franssen, F., Opsteegh, M., van der Giessen, J.W., Lipman, L.J.A., Overgaauw, P.A. (2018). Zoonotic bacteria and parasites found in raw meat-based diets for cats and dogs. Veterinary Record, 182 (2), 50-50.

35. Weber, A., Wachowitz, R., Weigl, U., SchäferSchmidt, R. (1995). Occurrence of Salmonella in fecal samples of dogs and cats in Northern Bavaria from 1975 to 1994. Berliner und Münchener Tierärztliche Wochenschrift, 108 (11), 401-405. 


\section{SALMONELLA SPР. У ХРАНИ ЗА КУЋНЕ ЉУБИМЦЕ И РИЗИК КОЈИ ПРЕДСТАВЉА ЗА ЗДРАВЉЕ ЉУДИ}

Дубравка С. Миланов ${ }^{1}$, Невенка Р. Алексић ${ }^{*}$, Сузана С. Видаковић ${ }^{1}$, Драгана Б. Љубојевић ${ }^{1}$, Ивана С. Чабаркапа ${ }^{3}$

${ }^{1}$ Научни институт за ветеринарство „Нови Сад“, 21000 Нови Сад, Руменачки пут 20, Србија

${ }^{2}$ Универзитет у Београду, Факултет ветеринарске медицине, 11000 Београд, Булевар ослобођења 18, Србија

${ }^{3}$ Универзитет у Новом Саду, Научни институт за прехрамбене технологије у Новом Саду, 21000 Нови Сад, Булевар цара Лазара 1, Србија

Сажетак: Комерцијална храна за псе и мачке је скоро непознат извор инфекције људи бактеријама из рода Salmonella. Људи се могу инфицирати директним контактом са контаминираном храном за кућне љубимце или контактом са кућним љубимцима који уобичајено излучују салмонеле без клиничких знакова инфекције. Иако се нови тренд исхране паса и мачака сировом храном са тог аспекта разматра као посебан ризик (јер ова храна уобичајено садржи храном преносиве патогене као што су Salmonella spp., Escherichia coli и Campylobacter spp.), епидемиолошки подаци не подржавају овакав став. У овом раду сумирамо релеватне податке о значају хране за кућне љубимце у појави салмонелоза људи, као и препоруке за превенцију појаве инфекција изазваних салмонелама из овог извора.

Кључне речи: кућни љубимци, сирова и комерцијална храна, салмонелоза

Received: 12 March 2019

Received in revised form: 5 April 2019

Accepted: 11 April 2019 